UDC 811.111'42

DOI https://doi.org/10.32841/2409-1154.2020.46-2.5

\author{
Mintsys E. Ye., \\ Senior Lecturer at the Department of English Philology \\ Vasyl Stefanyk Precarpathian National University
}

\author{
Mintsys Yu.B., \\ Candidate of Philological Sciences, \\ Associate Professor at the Department of English Philology \\ Vasyl Stefanyk Precarpathian National University
}

Pavliuk I. B., Candidate of Philological Sciences, Associate Professor at the Department of English Philology Vasyl Stefanyk Precarpathian National University

\title{
DIMINUTIVE-BASED COMMISSIVE SPEECH ACTS IN CHILDREN'S PROSE DOMAIN
}

\begin{abstract}
Summary. The article deals with English diminutives from the perspective of Speech Act Theory. Central to the research are commissive speech acts, which are performed either by the speaker or by both the speaker and the hearer. Those speech acts imply that the speaker is obliged to behave in a certain way. Besides, special attention is paid to the main word-building patterns of forming diminutives (synthetic and analytical). The article follows the theoretical postulates of J. Searle, K. Schneider, A. Wierzbitska, etc., and considers the ideas put forward by contemporary scholars (e.g. P. Biały, A. Buriakovskaia, A. Kiklewicz). The corpus of the study is based on popular writers' works for children (e.g. R. Dahl, J. Strong, J. Wilson) wherein the defined diminutive-based commissive speech acts comprise those of offer, announcement, suggestion, promise and threat. It has been found that diminutives in offers are realized for minimizing the speaker's efforts and the hearer's benefit, and for saving his/her "face". In announcements diminutives contribute to minimizing the speaker's benefit while in suggestions they serve for minimizing the hearer's efforts. In promises diminutives function for minimizing the speaker's responsibility for his/her words in case of not fulfilling the promise. In threats diminutives modify the speaker's responsibility for what has been said, and testify to increasing inner emotional tension and the conflicting features of the dialogue. The results of the empirically-based study are presented in the quantitative analysis of English diminutives in children's prose, which estimates the number of their occurrences in the above mentioned speech acts. It testifies that diminutivity is most frequently realized in the commissive speech acts of suggestion and threat. The minimal number of diminutive occurrences is found in the speech acts of offer.
\end{abstract}

Key words: diminutive, diminutivity, speech act, offer, announcement, suggestion, promise, threat.

Introduction. Speech Act Theory has been in the focus of attention of scholars' research in pragmatics (e.g. J. Austin 1975; J. Searle \& D. Vanderveken 1985; Van Dijk 2009; A. Wierzbitska 1991; D. Wunderlich 1980). Consequently, there have been created various taxonomies of speech acts. Commissives' presence in most of them accounts for the objective of this paper: to analyze the peculiarities of commissive speech acts based on diminutives.
As diminutivity needs a more extensive investigation and deserves a more careful consideration, it is viewed from the perspective of its pragmatic properties, with the emphasis on the speech act theory. Speech acts being context oriented (i.e. "rarely occur as independent of the communicative context" [1, p. 76]) and diminutives being typical of "communication with or by children or in children's stories" [2, p. 118], children's prose domain presents the target material of this study (e.g. works by R. Dahl, J. Wilson, J. Strong, etc.). The novelty of the current research results from the analysis of diminutives from the perspective of the speech act theory in the abovementioned domain. The corpus comprises forty-one diminutive-based commissives selected by means of employing the manual selection procedure. The total number of pages of the texts is over one thousand.

Diminutives are vocabulary units, which either denote a small size, "express an attitude on the part of the speaker towards the referent", or "serve different pragmatic functions in interpersonal interaction" signalling "emotional closeness, affection and informality" [3, p. 289]. From the point of view of their formation, there are two main types of diminutives in English: synthetic and analytical. Synthetic diminutives are those, which are formed by means of affixation. K. Schneider [4] distinguishes fourteen diminutive suffixes in contemporary English. According to A. Buryakovska the semantics of diminutives in English is of Germanic origin, although it develops under the influence of close contacts with various linguocultures [5]. It results in the presence of foreign-origin suffixes in English diminutives. The diminutive suffixes -ine, -ette, -otte are borrowed from French; -y, -ee, -ie, -ey - from Scottish dialect; -let - from Middle English, from Middle French -elet; -etto, -ett, -illa, -illo - from Italian and Spanish, etc. [6, p. 30]. Analytical diminutives are formed according to the pattern 'adjective+noun' with the help of the adjectives little, small, tiny, teeny, teeny-weeny, wee, petite, miniature, microscopic, minute, etc. In addition, there are other types of diminutive formations: reduplicative forms (e.g. Rosy-Posy), an echo-word formation (e.g. teeny-tiny), hypocoristic forms (e.g. Edward - Ed - Eddie) [7, p. 77-78].

Commissives are speech acts (SA) that are related to future actions. However, unlike directives, whose actions are performed 
by the hearer, commissives' actions are performed either solely by the speaker or by both the speaker and the hearer. According to Searle [8, p. 37] "in utterances with the commissive point the speaker commits himself to carrying out the course of action represented by the propositional content". Commissives oblige the speaker to behave in a certain way [8, p. 124; 9, p. 182-183]. The illocutionary verbs to denote this SA are promise, guarantee, vow, suggest, foresee, agree, etc. Their umbrella locution is "I'll do my best", "I'm likely to do", "I promise that I probably will", and others.

Results and discussion. As the result of the analysis there have been found occurrences of the diminutive-based commissive SA of offer, suggestion, announcement, promise and threat.

\section{Speech acts of offer}

The speech act of offer refers to the future action performed by the addresser, which is beneficial for the addressee. According to the classification proposed by K. Schneider, all the SA of offer are divided into offering help (they do not depend on the context and situation, however, result from social norms) and conventional offer of hospitality (they are limited by specific situations with definite social roles and norms) [4, p. 181]. Lorena Pérez Hernández [10, p. 311] distinguishes such types of offers: (1) those which involve the transfer of the object from the speaker to the addressee; (2) those which simply involve the performance of the speaker of an action which is beneficial to the addressee. In the SA of offering hospitality, the speaker acts when he/she is obliged to make an offer and the hearer is obliged to accept the offer, because in terms of politeness it is unacceptable to reject an offer of hospitality. It is the addressee of an offer that is expressed by a diminutive. In this case, the diminutive functions as a material category, not as a social one.

The SA of offering hospitality can be interpreted in the following way: "I want you to accept $\underline{Z}^{\text {Iem }}$ - supposing that you can refuse to take what I am giving you, and wishing to make you do what I tell you to by referring to its small size or its unimportance: I want you to accept $\underline{\underline{Z} \text { dim } ": ~}$

(1) 'Then take something, ma'am, 'said Mr. Bumble soothingly. "A little of the wine?" [11].

In (1) the speaker uses the diminutive little in order to diminish the number of his efforts and the amount of the hearer's benefit, respectively. Moreover, it is done not just to offer a little amount of wine, but, on the contrary, to have the interlocutor accept the offer which she will not be able to reject, only on condition that it does not contradict social norms (explicitly "Well, I will, only if just a little").

Thus, diminutives in the SA of offering hospitality are used as the means of the politeness strategy for saving the interlocutor's "face":

(2) "It must be a very pretty dance," said Alice timidly. "Would you like to see a little of it?" said the Mock Turtle [12].

In the SA of offering help the addresser expresses his/her wish to help the addresser in some way. K. Schneider states that diminutives modify only the SA of offering hospitality, not offering help. In case the latter are diminutive-based, they are found to be threatening the addressee's "face": if his/her efforts of performing an action are minimized, the addresser's help will be useless [4, p. 182]. However, in the given research, we found occurrences of the SA of offering help, which are modified by diminutives:

(3) "I'll take little Clive off your hands for an hour or so," she offered [13, p. 74].
In (3) the addresser-child offers the addressee-mother help in taking care of the younger brother. The diminutive little Clive is an inner diminutive, i.e. the one used for expressing attitude rather than modifying the illocutionary force.

However, theoretically, in the SA of offering help there can occur diminutives modifying the illocutionary force of the SA. E.g. "Can I give you a little help?" This artificially formed SA of offering help implies that the addresser minimizes his/her efforts for saving the addressee's "face" and benefit (explicitly "If the help is insignificant, you will not reject it").

\section{Speech acts of announcement}

The speech act of announcement is related to the future action performed by the speaker and for the speaker's benefit only. In this SA the speaker performs an action of his/her own accord and benefits from it. The future action announced by the speaker depends neither on the speaker's nor on the hearer's agreement. In this case, the hearer does not benefit from it and does not make efforts.

The diminutive-based SA of announcement can be rendered in the following way: "I am planning to do $\underline{Z}^{\text {dem }}$ - supposing that you may dislike what I am going to do, and wishing to avoid your negative reaction, I say, referring to the small size or unimportance of what I am going to do: I am planning to do $\underline{Z^{\text {tem }}}$ ".

In the SA of announcement, the addresser predicts an action, which he/she is planning to do in the future, and is going to benefit from. In this case, the diminutive is used for the sake of minimizing the positive effect of the action on the addresser and avoiding the addressee's negative criticism:

(4) "I'm going to be my mum's little treasure" [14, p. 169].

In (4) the diminutive aims at minimizing the degree, amount, size of the benefit for the addresser (little treasure instead of treasure).

\section{Speech acts of suggestion}

The speech act of suggestion presupposes benefit for both participants of conversation who are going to perform an action together. Thus, they are going to share the efforts and benefit of the suggestion. The SA of suggestion can be considered as directive commissives because they comprise two components: directive (the speaker wants the hearer to perform an action) and commissive (both the speaker and the hearer are responsible for performing an action, whose performance depends on the hearer's agreement).

The SA of suggestion implies: "I wish we would do $\underline{Z}^{\mathbf{d e m}}-$ supposing that you can be unwilling to do what I want us to $\overline{d o}$, wishing to make you do it, I say bv referring to its small size, unimportance. easiness or pleasantness: I want us to do $\underline{Z}^{\mathrm{Zem}}$ ”.

Diminutives in the SA of suggestion refer to the future event whose importance is "diminished" with their help for the addressee to more willingly agree:

(5) "What say if we do a little work for our supper?" He cried, rippling his muscles. "Come on, fellers! Who's for some exercise?" $[15$, p. 9].

In (5) the addresser encouraging his colleagues to work employs the analytical diminutive little work, minimizing the number of efforts to be made by the addressee.

The SA of suggestion can be aimed at the addressee's (6) or both addressee and addresser's preferences (7):

(6) "What about asking Granny and Lancelot if they've seen them?" [16, p. 19].

In (6) the commissive with the illocution of suggestion-compulsion is realized. It is notable that one of the objects is used 
in a diminutive form, and the other one in a full form. The fact is that the woman is the grandson's blood grandmother while the man is his step-grandfather. Therefore, the boy uses the non-diminutivized name Lancelot to demonstrate cold attitude to him; on the contrary, he refers to his grandmother as Granny, which testifies to his affection and positive attitude to her. In such patterns as what about, would you like, do you fancy, the decision whether the action is going to be fulfilled entirely depends on the hearer.

(7) I gave him a push and waved at Football. "Come on, let's play footie then. I'll give you a real game” [14, p. 142].

Example (7) demonstrates the situation when the diminutive is to create a friendly atmosphere, empathy and positive attitude to the suggested object, because in such a way the addresser demonstrates his wish to achieve the perlocutionary effect and encourages the hearer to act. Both the hearer and the speaker make a decision about performing an action (let $\underline{\boldsymbol{u} \boldsymbol{s}}$ ). The given example testifies to the fact that diminutives in the commissive SA are formed not only analytically but also synthetically. The stronger perlocutionary effect of synthetic diminutives requires further research, however, this type of diminutives in the commissive SA are stronger in terms of expressiveness.

\section{Speech acts of promise}

The speech act of promise is a prototypical commissive. Among all the commissive SA, promise implies the strongest degree of commitment. It is carried out at the initiative of another person (the one who is given a promise) and it is usually not the speaker who benefits from it. According to A. Weirzbicka [17, p. 207] "one of the most intriguing aspects of promises is related to the obligation which this act imposes on the speaker". The scholar views the obligation as a way of achieving the real point of an act of promising. It is notable that $\mathrm{K}$. Schneider did not find a single example of promise modified by diminutives $[4$, p. 179]. He attributes it to the fact that the use of diminutives can question the sincerity of the fulfilled promise. However, in our corpus such examples do occur:

(8) Of course, there isn't anything you can do to help Mrs. Quack, but as I told you in the beginning, what you can't do others can. Now I don't say that I can help Mrs. Quack, but I can try. I believe I'll do a little thinking myself [18].

In (8) the speaker gives the addressee a promise to save the bird. It is necessary to justify why this example presents the SA of promise not any other one. It cannot be the SA of announcement, because the speaker does not benefit from performing the action. It can neither be the SA of offer because the speaker does not offer anything to the addressee. Thus we treat it as the SA of promise in which the diminutive functions for minimizing the speaker's responsibility for his words in case of not fulfilling his promise.

The diminutive-based SA of promise can be interpreted in the following way: "I promise to do $\underline{\underline{Z}} \underline{\text { dem }}$ - supposing that you want me to do Z, wishing to have you think that I am obliged to do it and avoid your negative reaction in case I cannot do it, I say: I want to do $\underline{Z}$ dem $"$.

\section{Speech acts of threat}

The speech act of threat differs from that of promise because it is performed not for the benefit of the addressee. According to another assumption speech acts of threat and promise "share with other commissives a requirement for satisfaction of a condition on their propositional content, which must describe a future action or omission, or a sequence of such actions or omissions, by the speaker" [19, p. 216-217]. K. Bach and R. Harnish [20] state that threat is a directive commissive. On the one hand, the addresser wants the addressee to perform action 1 (directive), on the other hand - the addresser pledges to perform action 2 in the future (commissive) in case action 1 has not been performed, e.g.:

(9) "Now button that lippy little mouth of yours or I'll set light to you" [14, p. 207].

Lorena Pérez Hernández [10, p. 265] considers the directive-commissive hypothesis erroneous and suggests that "peripheral members of the threat category can have a higher degree of politeness as they gradually fade into a more polite speech act like warning". However, in our corpus there are no occurrences to illustrate this assumption.

We consider that a diminutive can be used in the SA of threat in order to amplify expressiveness and antagonism, i.e. it is realized for intensifying the seriousness of the situation rather than for minimizing the illocutionary force of threat.

Moreover, a diminutive in threat can be employed for expressing a familiar attitude and displaying superiority of the speaker over the hearer. In this case, the effect of familiarity is created by means of diminutizing the name of the hearer as well as that of the speaker or the referent.

(10) "Raymond slapped him on the cheek, hard. 'Now, now.' He said. 'Don't fight with auntie, not unless you want to get 'urt', [15, p. 92].

Diminutive can modify the directive suggestion like in example (10) or modify the commissive suggestion like in (11):

(11) "When I get back to the station, I'm going to do a little checking up on you," he said to my passenger. "Me? What've I done wrong?' The rat-faced man asked" [15, p. 33].

Thus, in (11) the use of analytical diminutive does not imply minimizing the speaker's responsibility for what has been said in case of not carrying out the threat. It highlights increasing inner emotional tension and the conflicting features of the dialogue. Examples (10) and (11) emphasize the difference of realizing diminutives in the promise and threat as the latter is most threatening SA for the hearer's "face". On the one hand, it ignores the need of the hearer in negative politeness, and on the other hand, it downgrades the image by a non-serious, familiar attitude. A familiar attitude is also rendered by a synthetic diminutive in the commissive offer:

(12) "You bears get out of here or I will fetch my daddy, who is a hunter" [21, p. 14].

A diminutive-based SA of threat can be interpreted in the following way: "I will do $\underline{\underline{Z}} \underline{\text { dem }}$ - supposing that you do not want me to do Z, wishing to let you know it beforehand, and willing to express my familiar attitude, I say: "I will do $\underline{\underline{Z}} \underline{\text { dem }}$."

Table 1

Diminutive occurrences in the commissive speech acts

\begin{tabular}{|l|c|c|}
\hline $\begin{array}{c}\text { The type of the } \\
\text { commissive speech act }\end{array}$ & $\begin{array}{c}\text { The number of } \\
\text { diminutive occurrences }\end{array}$ & The ratio, \% \\
\hline Offer & 2 & 4,9 \\
\hline Announcement & 6 & 14,6 \\
\hline Suggestion & 15 & 36,6 \\
\hline Promise & 8 & 19,5 \\
\hline Threat & 10 & 24,4 \\
\hline Total & 41 & 100 \\
\hline
\end{tabular}


Conclusions. The findings of the present study demonstrate that there have been analyzed such diminutive-based commissive speech acts as offer, suggestion, promise and threat. Diminutives in offers are realized for minimizing the speaker's efforts and the hearer's benefit, and for saving his/her "face". In announcements diminutives contribute to minimizing the speaker's benefit while in suggestions they serve for minimizing the hearer's efforts. In promises the diminutive functions for minimizing the speaker's responsibility for his words in case of not fulfilling his promise. In threats diminutives modify the speaker's responsibility for what has been said in case of not carrying out the promise, and testify to increasing inner emotional tension and the conflicting features of the dialogue. The data of the quantitative analysis of diminutive-based commissive speech acts demonstrate in Table 1 that diminutives in speech acts of order $(43.1 \%)$ and demand $(24.6 \%)$ have been most frequently used in children's prose, while diminutives in speech acts of pleading (13.8\%) have been the least frequently used.

As for the prospects for the future research, they consist in analyzing the peculiarities of diminutive occurrences in other speech acts, e.g. representatives, expressives.

\section{References:}

1. Kiklewicz A. The Hierarchical System of Speech Acts. Lingua Posnaniensis, 2011. LIII (1). P. 65-81.doi: 10.2478/ v10122-011-0005-6. URL : https://content.sciendo.com/view/journals/ linpo/53/1/article-p65.xml?language $=$ en (Accessed 17.01.2021).

2. Biały P. Synthetic Diminutives in English Nursery Rhymes: Formations with the suffix -ie. Prace Naukowe Akademii im. Jana Dtugosza w Częstochowie, 2012. N. 8. P. 113-121.

3. Rosiak K. From Synthetic to Analytic? The Changing Use of Diminutive Expressions in Welsh. In Ahlqvist, Anders \& O'Neill, Pamela (eds.), Celts and Their Cultures at Home and Abroad. A Festschrift for Malcolm Broun. Sydney : Celtic Studies Foundation, University of Sydney, 2013. P. 289-310.

4. Schneider K. Diminutives in English. Tübingen: Max Niemeyer Verlag, 2003. $254 \mathrm{p}$.

5. Буряковская А. А. Диминутивность в английской языковой картине мира: дис. ... канд. филол. наук : 10.02.04. Тула, 2008. 153 с.

6. Mintsys E. Ye., Mintsys Yu. B. Theoretical Principles of Researching Diminutive. Journal of Vasyl Stefanyk Precarpathian National University. 2015. Vol. 2. № 2-3. P. 29-35.

7. Bystrov Y., Mintsys E., Mintsys Yu. English Diminutives in Children's Literature: A Case Study of Directive Speech Acts. SKASE Journal of Theoretical Linguistics, 2020. Vol. 17. № 5. P. 77-96. URL : http:// www.skase.sk/Volumes/JTL47/pdf_doc/05.pdf.

8. Searle J., Vanderveken D. The Foundations of Illocutionary Logic. Logic, Thought and Action. Cambridge University Press, 1985. P. 109-132.

9. Austin J. How to Do Things with Words, 2nd edition. Philosophical Papers. Oxford, MA: Harvard University Press, 1975. 192 p.

10. Hernández L. Illocution and Cognition: a Constructional Approach. Universidad de la Rioja: Servicio de Publicaciones, 2001. 366 p.

11. Dickens Ch. Oliver Twist. URL : http://www.readcentral.com/chapters/ Charles-Dickens/Oliver-Twist/028 (Accessed 10.01.2021).

12. Carroll Lewis. Alice's Adventures in Wonderland. URL : http:// www.readcentral.com/chapters/Lewis-Carroll/Alices-AdventuresinWonderland/012 (Accessed 20.12.2020).

13. Wilson J. The Mum-Minder. L.: Yearling, 1994. 96 p.
14. Wilson J. The Dare Game. L.: Corgi Yearling Books, 2001. 250 p.

15. Dahl R. The Wonderful Story of Henry Sugar and Six More. L.: Puffin Books, 2000. $225 \mathrm{p}$.

16. Strong J. My brother's famous bottom. L.: Puffin Books, 2007. 86 p.

17. Wierzbicka A. Semantics, culture, and cognition: universal human concepts inculture-specific configurations. New York: Oxford University Press, $1992.496 \mathrm{p}$.

18. Burgess T. W. The Adventures of Poor Mrs. Quack. URL: http://www. gutenberg.org/files/5846/5846-h/5846-h.htm (Accessed 20.01.2021).

19. Salgueiro A. Promises, Threats, and the Foundations of Speech Act Theory. Pragmatics. International Pragmatics Association. 2010. 20:2.213-228. URL : https://journals.linguisticsociety.org/elanguage/ pragmatics/article/download/2569/2569-5290-1-PB.pdf (Accessed 15.01.2021).

20. Bach K., Harnish R. Linguistic Communication and Speech Acts. The MIT Press Cambridge, Massachusetts, and London, England, 1979. URL: https://www.academia.edu/34217327/Linguistic_Communication_and Speech_Acts (Accessed 18.01.2021).

21. Ahlberg A. Ten in a Bed. L.: Puffin Books, 2003. 95 p.

Мінцис Е. Є., Мінцис Ю. Б., Павлюк І. Б. Комісивний мовленнсвий акт за участю демінутивів (на матеріалі англомовної дитячої прози)

Анотація. У запропонованій статті розглядаються англійські димінутиви 3 точки зору теорії мовленнєвих актів. У центрі уваги дослідження $є$ комісивні мовленнєві акти, які виконуються лише мовцем або мовцем і слухачем. Ці мовленнєві акти означають, що мовець зобов'язаний дотримуватися певної лінії поведінки. Крім цього, особлива увага приділяється основним словотворчим способам утворення англійських димінутивів (синтетичному та аналітичному). У процесі дослідження ми послуговувалися теоретичними постулатами Дж. Серля, К. Шнайдеpa, А. Вежбицької та інших лінгвістів, а також розглядали ідеї запропоновані сучасними науковцями (напр.: П. Б'яли, А. Буряковська, А. Кіклевич). На матеріалі дослідження художніх творів відомих дитячих англомовних письменників (напр.: Р. Дал, Дж. Стронг, Дж. Уілсон) визначено такі комісивні мовленнєві акти за участю димінутивів, як 'пропонування', 'оголошення', 'пропозиція', 'обіцянка' та 'погроза'. Демінутиви у пропонуваннях (offer) peaлізовані $з$ метою применшення затрати мовця та вигоди слухача, а також збереження його “лиця". В оголошеннях (announcement) за допомогою демінутивів применшується вигода мовця, а у пропозиціях (suggestion) демінутиви слугують для применшення затрат слухача. В обіцянках (promise) демінутиви модифікують відповідальність мовця за сказане у випадку недотримання слова, у погрозах (threat) вони демонструють підвищення емоційності внутрішнього стану та конфліктність діалогу під час погрози. Результати дослідження емпірічного матеріалу відображені у кількісному аналізі використання димінутивів у мовленнєвих комісивних актах в англомовній дитячій прозі (див. Табл. 1). Було виявлено, що найчастіше димінутивність реалізується у мовленнєвих актах пропозиції та погрози, а найменш поширеною димінутивність $€$ у мовленнєвих актах пропонування.

Ключові слова: димінутив, димінутивність, мовний акт, пропонування, оголошення, пропозиція, обіцянка, погроза. 